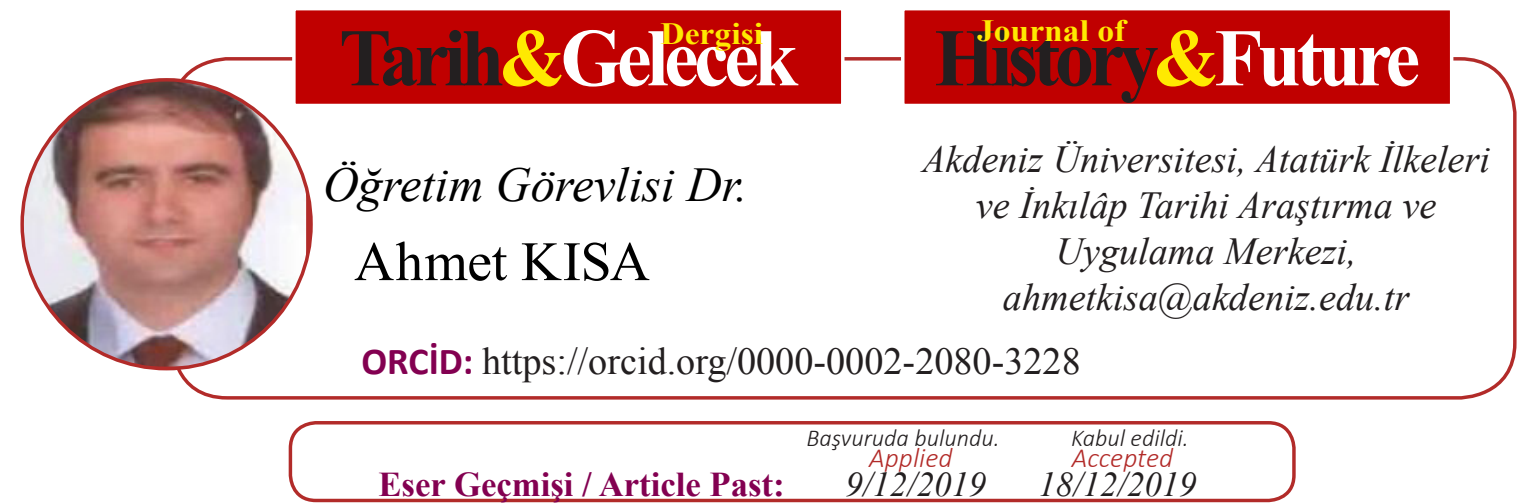

Araştırma Makalesi

DOI: http://dx.doi.org/10.21551/jhf.656920

Research Paper

Orjinal Makale / Orginal Paper

\title{
II. Meşrutiyet Dönemi’nde Bitlis Vilayeti’nde Karayolları
}

\author{
Highways in Bitlis Province During the Second Constitutional Era
}

\section{$\ddot{\mathbf{O z}}$}

Bu makale, II. Meşrutiyet Dönemi'nde (1908-1918) Osmanlı Devleti'nde karayollarının genel vaziyeti içerisinde Bitlis Vilayeti'nde karayollarının durumunu ortaya koymayı amaçlamaktadır. Bilindiği gibi yollar alt yapı hizmetlerinin temel taşı, bir ülkenin gelişmişlik düzeyinin en önemli göstergeleridir. Osmanlı Devleti'nde yolların inşasına özellikle 19. yüzyıl ortalarından itibaren önem verilmiş, bir dizi nizamnameler çıkarllarak yolların inşası ve tamiri hususunda önemli düzenlemeler yapılmıştır. II. Meşrutiyet Dönemi'nde de bu tutum devam ettirilerek yolların inşa edilmesine gayret sarf edilmiş, ancak fevkalade siyasi koşullar, bu koşullar çerçevesinde yolların yapılmasını gerekli kılmıştır. I. Dünya Savaşı 'na kadar daha çok umuma müteallik, Savaşla birlikte ise askeri açıdan gerekli olan yolların inşasına çalışılmıştır. Bu genel durum Bitlis Vilayeti'nde de yolların inşa edilmesine yansımış, askeri açıdan yapımının önem arz ettiği yolların inşasına öncelik verilmiştir. Ancak her vilayetin kendi varidatı miktarınca nafia bütçelerinin tanzim edilmesi Bitlis 'te vilayet varidatının azlı̆̆l sebebiyle yolların inşa edilmesinde büyük zorluklar yaratmıştır. I. Dünya Savaşı'nın yarattı̆̆ mali buhran merkezi hükümet tarafindan ayrılan tahsisatların yolların inşasına yetecek düzeyde olmasını engellemiş, Bitlis Vilayeti'nde yolların inşası konusunda gösterilen çabalar istenilen düzeyde yol yapımını sağlayamamıştır.

Anahtar Kelimeler: Bitlis, Karayolları, Yol, II. Meşrutiyet, Osmanlı Devleti.

\section{Abstract}

This article aims to reveal the state of the highways in Bitlis Province in the general state of the highways in the Ottoman Empire during the Second Constitutional Era (1908-1918). As is known, roads are the cornerstone of infrastructure services, and the most important indicators of a country's level of development. The construction of roads in the Ottoman Empire was especially important since the middle of the 19th century, and a number of regulations were issued regarding the construction and repair of roads. This attitude continued during the Second Constitutional Era and efforts were made to build roads, but the extraordinary political conditions made it necessary to build roads within the framework of these conditions. Until World War I, it was mostly attempted to construct public roads, with the war, however, roads that were necessary for military purposes were constructed. This general situation was also reflected in the construction of roads in Bitlis Province, and priority was given to the construction of roads, of which construction was important from a military point of view. However, due to the fact that public works budgets were arranged according to the amount of each province's own revenue and the scarcity of the province's revenue, great difficulties were experienced in the construction of roads. The financial depression of World War I prevented the fund allocated by the central government from being sufficient for the construction of roads, and the efforts made in the construction of roads in Bitlis province were not able to achieve the desired level of road construction.

Keywords: Bitlis, Highways, Road, Second Constitutional Era, Ottoman Empire.

ATIF: KISA Ahmet, "II. Meşrutiyet Dönemi’nde Bitlis Vilayeti’nde Karayolları" Tarih ve Gelecek

Dergisi, 5/3. (Aralık-2019), s. (702-711)

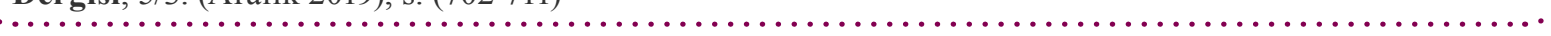

CITE: KISA Ahmet, "Highways in Bitlis Province During the Second Constitutional Era" Journal of

History and Future, 5/3 (December- 2019), pp. (702-711) 


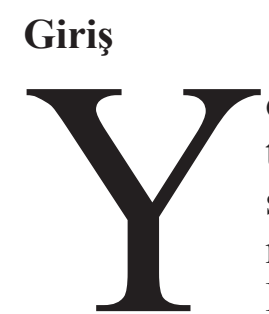

ollar bir ülkenin ilerlemesinin en önemli vasıtası, ekonomik büyümenin ve toplumsal kaynaşmanın en temel unsurlarından biridir. Yollarla köylerini kasabalara, kasabalarını kentlere ve önemli liman ve ticaret merkezlerine bağlamamış olan memleketlerin gelişmeleri mümkün olamaz. Bu nedenle Osmanlı Devleti'nde yolların inşasına büyük önem verilmiş, özellikle 19. Yüzyılın ikinci yarısından itibaren yolların inşası, mevcut olanlarının mütemadi bakımlarının yapılması için nizamnameler çıkarılmıştır’. En kapsamlısı 1898 yılında çıkarılan ve "Turuk ve Meâbir Talimatı Umumiyesi" adını taşıyan yol nizamnamesi ile daha evvel çıkarılmış olanların genel niteliğine bakıldığında yol düzenlemelerinin yolların tasnifini, yol yapımında görev alan memurlar ve vazifelerinin neler olduğunu, yolların hangi vasıflara göre yapılacağını tayin ettikleri görülür². Ancak II. Meşrutiyet Dönemi'ne kadar yol mevzuatının tayin ve tanzim edilmesi ile ilgili kanuni düzenlemeler yeterli olsa da bu dönemde yolların mevcut durumu ihtiyaçları karşılamaktan çok uzak kalmış, yol yokluğu bu döneminde önemli sorunlarından birini oluşturmuştur. Bu durum hükümetlerin yolların inşa ve tamiri hususlarına önemli surette eğilmesi gerekliliğini doğurmuştur.

\section{Meşrutiyet Dönemi'nde Karayolları}

1908 yılına kadar Osmanlı Devleti'nde inşa olunmuş, inşa olunmakta ve arada inşası tehir edilmiş olan yolların miktarı 30 bin kilometreyi bulmaktaydı. Bu yollar tam manası ile yapıldığı taktirde önemli merkezleri; birçok vilayet, sancak ve kasaba merkezlerini; başlıca iskele ve demiryolu istasyonlarını birbirine bağlamış olacaktı. Halihazırda yüzölçümleri dikkate alınmaksızın en çok yola malik olan vilayetler Hüdavendigar, Ankara, Manastır ve Sivas'tı. Osmanlı Devleti'nde toplamına nisbetle her yerden ziyade yola sahip ve yollardan en çok istifade eden vilayet İstanbul ve çevresiydi. II. Meşrutiyet Dönemi'ne kadar Osmanlı Devleti'nin Rumeli topraklarında İstanbulEdirne-Mustafa Paşa ile Selanik-Manastır-Yanya-Draç ve İşkodra'ya bağli; yine Üsküp-PriştineYenipazar-Seniçe arasında yollar söz konusuydu; ancak bu yollar üzerinde inşa olunmamış ya da tamirat gerektiren yüzlerce kilometre yol bulunuyordu. Osmanlı Devleti'nin Anadolu topraklarında ise İzmit-Ankara-Sivas-Malatya-Diyarbakır-Musul yolu birkaç noktası dışında iyi durumda değildi. Sivas-Erzincan yolu ile Erzincan-Eğin-Mamüret-ül Aziz yolu bitirilememişti. Bursa-Konya-Adana-Halep-Şam yolu üzerinde inşa olunmamış birçok kısım söz konusuydu. İnebolu-Samsun-Ordu-Giresun-Trabzon şehirlerinden iç bölgelere doğru Ankara-Çorum-YozgatSivas-Tokat-Şebinkarahisar-Erzincan-Erzurum merkezlerine bağlı olan yollarda henüz açılmamış kısımlardan başka yeniden tamiri lüzumlu yollar bulunuyordu³ .

1 Tanzimat'tan II. Meşrutiyet'e kadar Osmanlı Devleti'nde karayollarının durumu, karayollarının yapımı ile ilgili düzenlemeler hakkında bkz. Emrah Çetin, Tanzimat'tan II. Meşrutiyet'e Anadolu'da Karayolu Ulaşımı, Türk Tarih Kurumu Yayınları, Ankara 2017, s. 89-131; Şenay Atam, Osmanlı Devleti'nde Nafia Nezareti, Yayımlanmamış Doktora Tezi, Niğde Üniversitesi Sosyal Bilimler Enstitüsü, Niğde 2015, s. 194-369. II. Meşrutiyet Dönemi'nde Osmanlı Devleti’nde karayollarının durumu hakkında ise bkz. Ahmet Kısa, Osmanl Devleti'nde Baylndırlık Faaliyetleri (1908-1918); Kapitülasyonlar, İmtiyazlar, Anonim Şirketler, Yayımlanmamış Doktora Tezi, Akdeniz Üniversitesi Sosyal Bilimler Enstitüsü, Antalya 2019, s. 189-294.

21898 tarihli Turuk ve Meâbir Talimatı Umumiyesi için bkz. Nazım Berksan, Yol Davamız, Akın Matbaası, Ankara 1951, s. 33-55.

3 Umur-1 Nafiaya Dair Layiha, 1908: 20-21. 
Yolların mevcut durumu 1908 yılında esaslı bir nafia programının hazırlanmasını gerekli kı1mış, 14 Aralık 1908 tarihinde Umur-1 Nafia'ya Dair Layiha hazırlanmıştı. 1908 Nafia Programında 8 sene içerisinde 30.044 kilometre yol yapılması ön görülüyordu. Ancak bu programın uygulanması için gerekli olan mali kaynak temin edilememiş, dış borç alımı yoluyla işlerin icra edilmesine ise Meclis-i Mebusan onay vermemişti ${ }^{4}$. Bu durumda yolların yapımı her yıl bütçe tanziminde vilayetlere ayrılan nafia bütçesiyle sınırlı kalacaktı. Bununla birlikte 1909 yılında yollar ve köprüler inşaatlarının daha hızlı bir şekilde yapılmasını temin etmek için vilayet tarik bedellerini teminat göstererek 10-12 yıllık borçlanmaları mümkün kılacak düzenleme yapıldı, tarik işleri Muvazene-i Umumiye Kanunu'nun bu tür borçlanmaları engelleyen 9. Maddesinden muaf tutuldus.

\section{Bitlis Vilayeti'nde Yollar}

1878 yılında vilayet olan Bitlis, 1908 yılı itibariyle merkez Bitlis Sancağı dışında Muş, Siirt ve Genç sancaklarından oluşuyordu ${ }^{6}$. Bitlis Vilayeti'nin önemli sorunlarının başında ulaşım geliyordu, çoğu yerde yollar doğal çığırlardan müteşekkil olmakla birlikte, halihazırda mevcut olanlarda esaslı bir tamire muhtaç bulunuyordu, yollar üzerinde bulunan köprülerin tamirden geçirilmesi gerekiyordu'. Bu nedenle Vilayet Meclisi'nin 31 Mayıs 1909 tarihli toplantısında Bitlis Vilayeti'ne bağlı kazaların çoğu tarafından hususi yollar üzerinde bulunan köprülerin inşa edilmesi istenmişti. Ancak devlet yolları üzerinde bulunan köprülerin ehemmiyetine karşı bu gibi yol ve köprülerin ikinci ve üçüncü derecede kalacağı, dolayısıyla 1909 yılında öncelikli olarak tarik-i umumi (devlet yolları) üzerindeki köprülerin biran evvel yapılması, hususi yollar (vilayet yolları) üzerinde bulunan köprülerin inşasının ise gelecek seneye ertelenmesi kararlaştırılmıştı ${ }^{8}$.

Bitlis Vilayeti'nde yolların inşa edilmesi hususunda önemli bir çaba Bitlis'te Sancak Mutasarrıfi iken 3 Şubat 1909 tarihinde Bitlis Vilayeti'ne vali olarak tayin edilen ve 15 Temmuz 1909 tarihine kadar bu görevde kalan Mehmet Hüsnü Bey tarafindan gösterilmişti ${ }^{9}$. Hüsnü Bey 26 Haziran 1909 tarihinde Sadaret'e göndermiş olduğu telgrafta Bitlis Vilayeti'nin en büyük perişanlığının başında yol ve köprülerden mahrumiyet olduğunu ifade etmiş̧ti. Vilayette son derece harap bir halde bulunan iki yol olduğunu bildiren Hüsnü Bey, bu yollardan birinin Muş, Hınıs ve Erzurum üzerinden Trabzon sahiline; diğerinin ise Diyarbakır ve Halep üzerinden İskenderun İskelesi'ne bağlı olduğunu, her ikisinin de askerlik ve ticaret açısından yegâne ulaşım unsurlarını oluşturduğunu belirtmişti. Bu yolların tamiri, bazı kısımlarının yeniden yapılması, güzergâhlar üzerinde köprülerin inşa edilmesi gerekiyorken, Vali Bey vilayette görevine başladığında nafia memurlarının elinde yollarda yapılacak tamir ve inşaatlar için hazırlanmış keşif evraklarının bile bulunmadığını hayretle görmüş, hemen harekete geçerek yapılacak yollardan bir kısmının keşif evraklarını peyderpey tanzim ettirmişti. Keşifleri yapılan yolların evraklarını muhtelif tarihlerde Nafia Nezareti'ne göndermişti. Keşifleri yapılan yollar ile inşaat için gerekli olan harcama miktar-

4 MMZC, 1. Dönem, 1. İçtima, 5. Cilt, İ. 105, 20 Haziran 1325/3 Temmuz 1909, s. 147-157.

5 MMZC, 1. Dönem, 1. İçtima, 6. Cilt, İ. 137, 5 Ağustos 1325/18 Ağustos 1909, s. 539-540.

6 Bülent Cırık, İkinci Meşrutiyet Döneminde Bitlis Sancağı (1908-1914), Yayımlanmamış Doktora Tezi, Sakarya Üniversitesi Sosyal Bilimler Enstitüsü, Sakarya 2015, s. 19-22.

7 İsmail Hakk1 Bey, Raporlarım, Osmanlı Matbaası, Adana 1328 (1912). İsmail Hakk1 Bey'in hayatı ile ilgili bkz. Yıldıray Yıldırım, "Bir Devlet Adamı Olarak İsmail Hakkı Bey ve Adana Valiliği Dönemi’ndeki Faaliyetleri (1914-1916)", Ed. Erdem Çanak, M. Fatih Sansar, II. Uluslararası Multidisipliner Çalışmaları Kongresi, Akademisyen Kitabevi, Ankara, s. 92-99.

8 BOA, DH. MKT. 271-94, H. 21.6.1327/10 Temmuz 1909.

9 Danyal Tekdal, II. Abdülhamit Dönemi'nde Bitlis Vilayeti (İdari ve Sosyal Yapl), Yayımlanmamış Doktora Tezi, Pamukkale Üniversitesi, Sosyal Bilimler Enstitüsü, Denizli 2018, s. 46-47. 
ları Vilayet Meclisi'nin 5 Haziran 1909 tarihli mazbatasında yer almıştı. Buna göre, 427.000 kuruş Bitlis, Muş, Genç; 104.500 kuruş Muş, Hınıs; 100.000 kuruş Bitlis-Diyarbakır; 200.000 kuruş Siirt-Ziyaret; 79.000 kuruş Genç Sancağ 1 yollarına ve 39.500 kuruş acilen tamiri gerekli yollar ile 250.000 kuruş bunlar dışında ortaya çıkan diğer inşaatlar için tahsisat ayrılması kararlaştırılmıştı. Hattızattında bu tahsisatlar Nafia Nezareti'nin 14 Aralık 1908 tarihinde hazırlamış olduğu Nafia Programı'nda Bitlis Vilayeti için fevkalade bütçede 2.100.000 ${ }^{10}$ kuruşluk sarfiyat ayrılmış olmasına dayanıyordu ve Vilayet Meclisi'nin yapılacak işlerle ilgili talep ettiği 1.200.000 kuruşluk tahsisat isteğine ruhsat verileceği düşünülmüştü.

Ancak düşünüldüğü gibi olmadı; 3 Haziran 1909 tarihinde Ticaret ve Nafia Nezareti'nden Vilayet'e gönderilen telgrafta tadil olunan umumi bütçede Bitlis Vilayeti'nde yol inşaat ve tamiratı için 119.000 kuruş vaz olunduğu bildirilmiş, bu tahsisatın hangi yollara ne miktarda harcanacağ 1 belirtilmişti. Bitlis Vilayeti'ne 1909 yılı için tahsis olunan miktar oldukça azdı ve bu para ile vilayette yol yapmak ve tamir etmek neredeyse imkânsızdı. Dolayısıyla durum birkaç defa Nezarete bildirilerek, tahsisatın arttırılması talep edildi ${ }^{11}$. 24 Haziran 1909 tarihinde Nezaret'ten bu talebe verilen cevapta tahsisatın arttırılmasının mümkün olamayacağı bildiriliyordu. Hüsnü Bey, 29.000 kilometre yüz ölçümüne, 700 bin $^{12}$ nüfusa sahip bir vilayetin her yerden daha çok yola ihtiyaç duymasına rağmen tahsisatın bu derece az olmasına bir anlam veremiyor, bu durumun kendisini "sekine-i mahalliyyenin yüzüne bakamayacak" duruma soktuğunu Sadaret'e bildiriyordu"

Bitlis Vilayeti için 1909 yılı nafia bütçesi olarak sadece 119.000 kuruş tahsisat ayrılmış olması bazı nedenlere dayanıyordu. Daha önceden vilayetlerin nafia bütçeleri düzenlenirken genel varidatın \%5'i ile Ziraat Bankası'ndan alınan 40.000 liranın bu \%5'lere ilavesi sağlanıyor, her vilayetin bedelatı nakdiyesine göre o vilayetin nafia bütçesi tanzim ediliyordu. Bu hususlar dikkate alınarak 1909 yılında Bitlis Vilayeti'nin nafia bütçesi 20.000 lira olarak belirlenmişti. Ancak 1909 y1lında “1325 Y1l Muvazene-i Umumiye Kanun Layihası”nın 18. Maddesinde, her vilayetin tarik bedelinin yalnız o vilayetin turuk ve meâbirine harcanması kararlaştırılmışt1 ${ }^{14}$. Bu değişiklikle hem genel varidatın $\% 5$ 'leri nafia bütçelerinin tanziminde tahsisattan kaldırılıyor, hem de vilayetin son 5 yıllık bedelat-1 nakdiyesi dikkate alınarak bir düzenleme yapılıyordu. Bu durumda yol vergisini (bedelat-1 nakdiye) toplamakta zorluk çeken vilayetlerin nafia bütçeleri oldukça yetersiz kalıyor, bu rakam bu şartlarda Bitlis Vilayeti için ancak 119.000 kuruşa tekabül ediyordu ${ }^{15}$.

Bitlis Vilayeti'nde nafia işlerinin yapılması için yol vergisi miktarınca işlerin yapılması gerekliliği neredeyse vilayetin nafia hizmetleri noktasında boş bırakılması anlamına geliyordu. Nitekim bu durum yolların inşasında mesafe alınmasını engellemiş, 8 Ağustos 1910- 1 Kasım 1911

1014 Aralık 1908 tarihli Nafia Programında Turuk ve Meabir Bütçesi’nin vilayetlere dağılımı tanzim edilmiş; Bitlis Vilayeti için adi bütçede imalatlar ve mütemadi tamiratlar için 1.600 .000 kuruş, fevkalade bütçede imalatlar için 500.000 kuruş olmak üzere toplam 2.100.000 kuruş tahsisat ayrılmıştı. Umur-1 Nafiaya Dair Layiha, 1908: 27.

11 BEO 3588-269034, H. 12.6.1327/1 Temmuz 1909.

12 Bitlis Vilayeti'nin nüfusu hakkında kaynaklarda farklı rakamlar söz konusudur. Örneğin 8 Ağustos 1910 ile 1 Kasım 1911 tarihleri arasında Bitlis Vilayeti’ne vali olarak tayin edilen İsmail Hakkı Bey’in Bitlis Vilayeti hakkında Dahiliye Nezareti’ne yazdığı kapsamlı raporunda dahili vilayette kayıtlı olarak 395.910 nüfus mevcut olduğu, bunun 281.867 kadarının Müslüman, 114.043 kadarının ise gayrimüslim nüfusu teşkil ettiği belirtilmiştir. Ancak nüfusa kayıt edilmeyenler ile birlikte vilayetin yaklaşık olarak nüfusunun 600.000 civarında olacağı tahmin edilmekteydi. İsmail Hakkı Bey, Raporlarım, s.11.

13 DH. MKT. 2881-13, H. 02.07.1327/20 Temmuz 1909.

14 MMZC, 1. Dönem, 1. İçtima, 6. Cilt, İ. 132, 31 Temmuz 1325/13 Ağustos 1909, s. 388.

15 DH. MKT. 286-103, H. 17.06.1327/6 Temmuz 1909. 
tarihleri arasında Bitlis Vilayetine vali tayin edilen İsmail Hakkı Bey'in Bitlis Vilayeti hakkında Dâhiliye Nezareti'ne yazdığı raporunda vilayetteki yol yokluğu açık bir şekilde rapora yansımıştı. Hakkı Bey, Bitlis Vilayeti'nin en ziyade muhtaç olduğu ve en çabuk yapılmasına ihtiyaç duyulan şeyin yol olduğunu raporunda bildiriyordu. Şimdiye kadar Bitlis Vilayeti'nde 10-15 yıl önce açılan; ancak bitirilemeyen, zaman içinde inşa edilen kısımlarının da harap hale geldiği 50-60 kilometre civarında bir yol bulunuyordu. An itibariyle yollarında 30 kilometre şose yoldan ibaret olduğunu bildiren Hakkı Bey, "bir metre şoseye en az bir hesap ile yarım lira sarf edilmiş olduğunu kabul edecek olursak bu 30 kilometre için 15.000 lira kadar bir masraf vaki” olduğunu yazıyordu. Ancak bir metrelik yolun bu vilayet dâhilinde iyi bir şekilde muhafaza edilmesi için, bekçi masrafları, aletler ve diğer tamir masrafları da dâhil olduğu halde yıllık 1.5 kuruşa ihtiyaç duyduğunu belirten Hakkı Bey, 30 kilometrelik bir şosenin senelik masrafının 45.000 kuruşa baliğ olduğunu raporunda belirtiyor, "bizde şimdiye kadar bu cihetlere ehemmiyet verilmediği için bu gün hiçbir tarafta muntazam ve maksada kafi bir yolumuz bulunmuyor," diyordu ${ }^{16}$.

II. Meşrutiyet Dönemi'nde Osmanlı Devleti'nin diğer vilayetlerinde olduğu gibi Bitlis Vilayeti'nde de yolların inşa edilememiş olması gerekli sermayenin tedarik edilememesine dayanıyordu. 1910 yılında Osmanlı Devleti yolları, devlet yolları (turuk-1 umumi) ve vilayet yolları (turuk-1 hususi) olmak üzere iki kısma ayırmış, yapılmasının aciliyet gerektirdiği bazı vilayet yolları da dâhil edilerek 10.000 kilometre yolun inşası Fransız İnşaat Şirketi'ne ihale edilmişti. $\mathrm{Bu}$ yollar içerisinde Bitlis-Erzurum yolu da vardı; ancak Fransız İnşaat Şirketi memleketin her tarafında birden inşaata başlayamamış, ${ }^{17}$ Bitlis gibi vilayetlerde bu şirket tarafından hiçbir çalışma yapılamamıştı. Dolayısıyla Bitlis Vilayeti'nde yolların bu dönemde inşası genelde sonuçsuz kalan girişimlerle sınırlı kalmıştı.

Bu sınırlı girişimlere bakıldığında bölgede yolların inşası hususunda şu çalışmaların söz konusu olduğu görülür. Bu dönemde Adilcevaz'dan Erzurum ve Trabzon yoluna bağlanacak şosenin Diyarbakır, Bitlis, Harput, Kığı yollarının ve Turuk-1 Umumiye Şirketi'nin henüz inşasına başlamadığı diğer devlet yollarının yapılması için 1913 yılı Nafia Nezareti bütçesinin 15. Faslının 2. Maddesine zam yapılması Nafia Nezareti tarafindan istenmişti ${ }^{18}$.

Nafia Nezareti, ordu tarafından Erzurum, Bitlis ve Van Vilayetlerinin şose ile birbirine bağlanması ve böylelikle Van Gölü’ne ulaşan bir yol yapılması talebine karşı bazı gerekçeleri ileri sürerek daha farklı bir çözüm öneriyordu. Ordu tarafından yapılmasının istendiği yolların inşası için 500.000 lira dolayında bir tahsisat gerekliydi ve arazinin yol yapımına müsait olmaması dolayısıyla işin bir hayli vakit alacağı ifade edilerek Van Gölü'nde vapur işletilmesi teklif ediliyordu. Eğer bu yapılırsa yol inşasından beklenilen faydaların kısmen temin edileceği gibi bölge ekonomisi canlanacak ve daha az masrafla daha kısa zamanda sonuç alınmış olunacaktı. Bu amaçla Adilcevaz, Tatvan ve Van'da iskeleler tesisi için 15.000 lira tahsisatın şimdilik yeterli geleceği düşünülmekteydi. Daha sonra Diyarbakır, Bitlis, Harput, Kığı yolları geçici bir kanunla devlet yolları kapsamına alınacak, bu yollarda inşaatın mahalli idarenin tarik bedelleri tarafından meydana getirilemeyeceği için bu sene zarfında en azından yolların inşasına başlanmasını temin maksadıyla merkezi idareden 45.000 liranın daha ayrılması talep edilmişti ${ }^{19}$.

Nafia Nezareti'nin talebi 24 Haziran 1913 tarihinde Meclis-i Mebusan'da görüşüldü.

16 İsmail Hakk1 Bey, Raporlarım, s. 23/77-78.

17 II. Meşrutiyet Dönemi’nde Osmanlı Devleti’nin yolların inşası ile ilgili takip ettiği politikanın detayları için bkz. Kısa, Osmanlı Devleti'nde Bayındırlık..., s. 209-231.

18 MV. 176-64, H. 22.05.1331/29 Nisan 1913.

19 BEO, 4168-312582, H. 25.05.1331/2 May1s 1913. 
Diyarbakır-Bitlis yoluyla Erzurum-Kığı yolunun Harput'a kadar olan kısmı geçici kanunla devlet yollarına nakledildi, bu yolların inşa edilmesi için lazım gelen 4,5 milyon kuruşun ek tahsisatla Nafia Nezareti bütçesine konulması kararlaştırıld $1^{20}$. Diyarbakır-Bitlis yolunun inşası için merhum Mahmut Şevket Paşa tarafından Diyarbakır Valisine 50.000 liralık tahsisat gönderileceği vaat edilmiş olmasına rağmen ${ }^{21}$ ne vaat edilen 50.000 lira Vilayet-i Şarkiye' de yapılacak yollar için gönderilebildi ne de Nafia Nezareti'nin talep ettiği 4,5 milyon kuruş 1913 Nafia Bütçesine ilave edildi. Hazinenin mevcut durumunun en önemli işleri bile yapmakta zorlandığ1 gerekçe gösterilerek Şirket-i İnşaiye Programı dışında bırakılan devlet yollarının inşası için bütçeye ilave yapılmasının mümkün olmadığı, tehir edilmesinin gerekliliği 20 Ağustos 1913 tarihinde Maliye Nezareti'nden Sadaret'e bildirildi ${ }^{22}$.

Bu ahval içerisinde 1913 yılı sonlarında Bitlis Vilayeti'nde yolların durumu harita ve tabloda gösterildiği gibiydi ${ }^{23}$.

\section{Harita 1: Bitlis Vilayeti'nde Yollar (1913)}

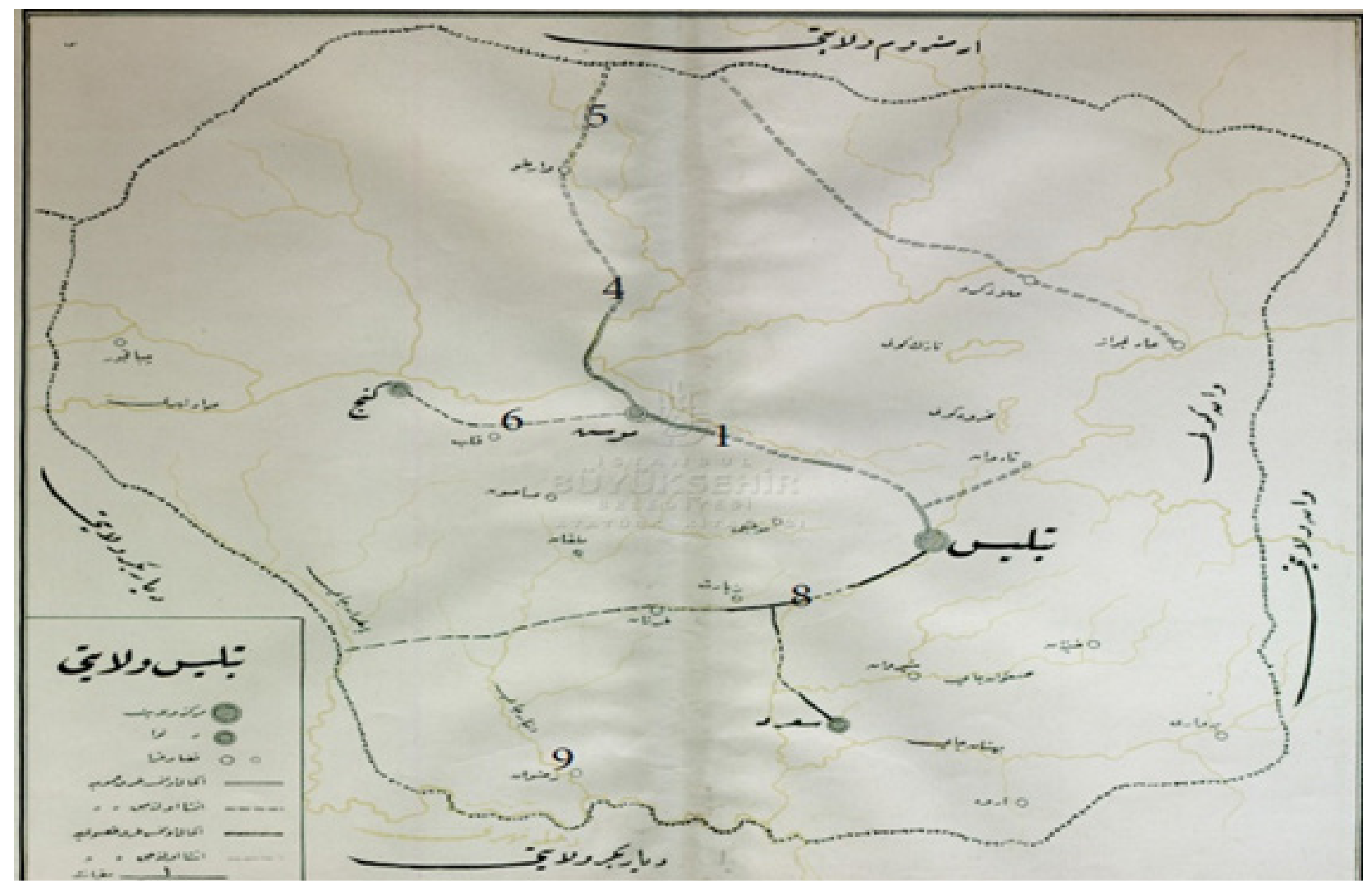

20 MV. 178-30, H. 19.07.1331/24 Haziran 1913; İ. MLU. 8-5, H. 03.09.1332/26 Temmuz 1914.

21 DH. İD. 3-18, H. 24.08.1331/29 Temmuz 1913.

22 BEO, 4206-315437, H. 17.09.1331/20 Ağustos 1913.

23 Harita üzerinde yol güzergâhları tarafımızdan numaralandırılmıştır. Gerek harita ve gerek tablo daha önce doktora çalışmamızda (Ahmet Kısa, Osmanlı Devleti'nde Bayındırlık Faaliyetleri (1908-1918); Kapitülasyonlar, İmtiyazlar, Anonim Şirketler, Yayımlanmamış Doktora Tezi, Akdeniz Üniversitesi Sosyal Bilimler Enstitüsü, Antalya 2019, s.253) kullanılmıştır. Vilayet Yolları Haritası, 1913. DH. UMVM. 74/31, 1333 M 15/3 Aralık 1914. 
Tablo 1. Bitlis Vilayeti’nde Yollar (1913)

\begin{tabular}{|c|c|c|c|c|c|c|}
\hline Yolların İsimleri & \multicolumn{2}{|l|}{ Şose } & \multicolumn{2}{|c|}{ Tesviye-i Türabiye } & \multirow{2}{*}{ 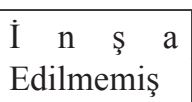 } & \multirow{2}{*}{$\begin{array}{l}\text { Top l a m } \\
\text { Uzunluk }\end{array}$} \\
\hline & & & & & & \\
\hline 1.Bitlis-Muş ${ }^{1}$ & & $50+000$ & $8+000$ & & $22+000$ & $80+000$ \\
\hline 2.Muş-Bulanık & & & & & $96+000$ & $96+000$ \\
\hline 3.Bulanık-Malazgirt & & & & & $25+000$ & $25+000$ \\
\hline 4.Muş-Varto & $9+000$ & $7+000$ & & & $27+000$ & $43+000$ \\
\hline 5.Varto-Hınıs & & & & & $42+000$ & $42+000$ \\
\hline 6.Muş-Genç & & & & & $60+000$ & $60+000$ \\
\hline 7.Genç-Palu & & & & & $100+000$ & $100+000$ \\
\hline 8.Bitlis-Ziyaret & $29+000$ & & & $29+000$ & & $75+000$ \\
\hline 9.Ziyaret-Rizvan ${ }^{2}$ & & & & & $81+000$ & $81+000$ \\
\hline
\end{tabular}

Tabloda da görüldüğü üzere 1913 yılı sonlarında Bitlis Vilayeti’nde yolların büyük kısmı inşa edilmemiş vaziyetteydi. Mali durum dolayısıyla Nafia Nezareti bütçesine ek tahsisat konulamaması zorunlu olarak yol ve köprü çalışmalarının durmasına neden olmuştu. Oysa yollar "istifadat-1 askeriyenin" tamamlayıcısı olmak dolayısıyla oldukça önemliydi. Birçok fedakârlıklarla Bağdat-Halep yolunun üç tarafından, Bitlis-Diyarbakır yolunun iki tarafından inşasına başlanmıştı. Nafia Nezareti, eğer tahsisat ayrılmazsa şimdiye değin yapılmış bütün çalışmaların boşa gideceğinden endişe ediyor, hiç olmazsa inşasına başlanılan yolların ikmal edilmesini Sadaret'ten istirham ediyordu ${ }^{24}$.

Bu sırada I. Dünya Savaşı dolayısıyla seferberliğin ilan edilmesi askeri açıdan yapılması lüzumlu olan yollar üzerinde biran evvel çalışma yapılmasını gerekli kılıyordu. Birçok yerlerde, özellikle de askeri açıdan yapılmasının zaruri olduğu yolların bulunduğu bölgelerde taş nakli ve dökülmesi gibi çalışmalar kadınlar tarafından yapılmaya, hatta 20 yaşından küçük 45 yaşından büyük olanların bile hizmetlerinden istifade olunmaya başlanmıştı. Hem ahali hem de yolların yapımında görev alan amele taburlarından istenilen seviyede faydalanabilmek, Diyarbakır-Bitlis, Diyarbakır-Urfa, Bağdat-Halep, Samsun-Sivas, Muş-Erzurum yollarında yol inşasının devamına lüzum görülen yerlerin inşası için gerekli olan alet ve edevatın biran önce tedarik edilmesine bağlıydı ve bu tür ihtiyaçların hızlıca karşılanması isteniyordu ${ }^{25}$.

Bitlis Vilayeti Sermühendisliği'nden Nafia Nezareti’ne gönderilen 18 Ağustos 1914 tarihli mektupta; ahval-i hazıra dolayısıyla yol inşaatlarının durduğu belirtilmekte, böyle buhranlı zamanlarda inşaatın durması tabii ise de asker nakli açısından önemli olan bazı yolların inşa masraflarının karşılanmasının zaruri olduğu belirtilmekteydi. Devlet yollarından Muş-Erzurum yolu üzerinde Karasu Köprüsü ile Murat Köprüsü'nün ${ }^{26}$ bu kabilden inşaatlar olduğu, köprülerin inşasına de-

24 BEO, 4306-322890, H. 25.09.1332/17 Ağustos 1914.

25 BEO, 4308-322053, H. 11.10.1332/2 Eylül 1914.

26 İsmail Hakkı Bey, Murat Çayı üzerinde bulunan köprünün 1903 yılında Malazgirt'te meydana gelen deprem sırasında yıkıldığııı, köprünün tamiri için birkaç kere heyetler gelmiş keşifler yapılmışsa da 1911 yılı itibariyle köprü üzerinde herhangi bir çalışmanın söz konusu olmadığını belirtmektedir. Bkz. İsmail Hakkı, Raporlarım, s. 44. Şen'in Muş köprüleri ile ilgili makalesinde bu tarihten öncede köprülerin iyi halde bulunmadığı anlaşılmaktadır. Bkz. Korkmaz Şen, "Osmanlı Arşiv Belgelerinde 
vam edilmekte iken masraflar dolayısıyla tadile uğradığı belirtilmişti. Bu köprüler olmadan Bitlis Vilayeti'nin Erzurum ile bağlantısı kesilmiş oluyor, Harput, Palu, Çapakçur, Kığı, Muş kısmından gelecek sevkiyat dahi mümkün olmuyordu. Bitlis Vilayeti Sermühendisliği hiç olmazsa bu iki köprünün inşasının bitirilmesi hususunda sarfiyat icrasına müsaade edilmesini talep ediyordu. Halihazırda teşkil edilen bir amele taburu ile Çapakçur-Palu yolu ile Çapakçur-Kığı-Muş yollarının inşası ve aynı zamanda Van'da oluşturulan bir amele taburuyla iki yönden Van-Bitlis yolunun inşası ordu tarafından kararlaştırılmıştı. Çapakçur yolu inşaatı için fen memurları bölgeye gönderilmiş, gerekli alet ve edevatın acilen teminine gayret sarf ediliyordu ${ }^{27}$. Seferberlik sebebiyle silah altına alınan gayrimüslim tebaanın ordu ile koordineli bir şekilde yapımının aciliyet arz ettiği yollarda çalıştırılması Bitlis Vilayeti'nden isteniyordu ${ }^{28}$. Nitekim 18 Kasım 1914 tarihinde Dâhiliye Nezareti'nin Bitlis Vilayeti'ne çekmiş olduğu telgrafta Cizre-Siirt arasındaki yolun biran evvel tamir ve ıslahı için 11. Kolordu Kumandanlığı ile muhabere olunarak işe derhal başlanması, neticenin Nezaret'e bildirilmesi talep edilmişti ${ }^{29}$.

I. Dünya Savaşı yıllarında Bitlis Vilayeti'nde yollar askeri ihtiyaçlar çerçevesinde tamir ve inşa sürecine tabii tutulmuş, yapılan çalışmalar bu çerçevede yürütülmüştü. Savaş koşullarında yolların tamiratında gösterilen çabalar ile yolların kullanımında ortaya çıkan yoğunluk aynı düzeyde olmadı. Seferberlik sonrası yollardan çok miktarda işleyen yük hayvanları ve kağnı arabaları mevcut yolları daha da tahrip etti, "kağnıların ince tekerlekleri yolları adeta bıçak gibi kesip harap ediyordu ${ }^{30}$." 1917 yılı başlarında Bitlis Vilayeti'nde; Bitlis-Tatvan-Muş-Hınıs-Erzurum arasında 106 kilometresi tamir isteyen, 142 kilometresi henüz açılmamış olmak üzere 248 kilometre devlet yolu bulunuyordu ${ }^{31}$. Bu durum II. Meşrutiyet Dönemi'nde Bitlis Vilayeti'nde yolların inşa ve tamiri konusunda istenilen neticenin elde edilemediğini göstermekteydi. Üstelik savaş koşulları yolların inşasında görevli memurların maaşlarının dahi ödenmesini imkânsız kılmış, Trabzon, Erzurum, Van ve Bitlis Vilayetleri ile Erzincan Sancağı'nda 1919 yılından itibaren “idare-i hususiye teşkilatının tatbik ve icra edilmemesinden" dolayı vilayetlerde bulunan fen memurlarının maaşları, harcırahları, levazım, yakacak bedelleri gibi ihtiyaçları karşılanamamıştı. Bu durum defalarca vilayetten merkeze durumu ifade eden yazışmaların yapılmasına neden olmuş, nihayetinde 9 Ağustos 1919 tarihinde bir kararname hazırlanmıștı. 2 Eylül 1919 tarihinde hazırlanan bu kararnamenin 3. Maddesine "Vilayet-i Müstahlis İdare-i Hususiye" masrafları olarak 70.000 liranın konulması kararlaştırılmıştı ${ }^{32}$. Ancak bu tahsisatların bile Bitlis Vilayeti’ne ulaşması mümkün olmadı.

\section{Sonuç}

II. Meşrutiyet Dönemi Osmanlı Devleti’nde 1908-1918 yıllarını içeren 10 yıllık dönemi kapsamaktadır. 23 Temmuz 1908 tarihinde meşrutiyetin yeniden ilanı, ardından Meclis-i Mebusan’ın çalışmalarına başlaması ile birlikte Osmanlı Devleti'nde kaynaşma, birçok konuda ilerleme beklentisi toplumda hâkim olmuştur. Yolların yapımı hususunda da aynı beklenti söz konusudur. Bu dönemde yolların inşası ile ilgili önemli çabalar gösterilmiş, 1908 Nafia Programında 30.044 kilo-

Muş Köprüleri”, Türkiyat Mecmuası, 2019, s. 6.

27

28

29

31

32

BEO, 4308-323089, H. 14.10.1332/5 Eylül 1914.

DH. ŞFR. 43-214, H. 18.09.1333/30 Temmuz 1915.

DH. ŞFR. 47-132, H. 05.01.1333/23 Kasım 1914.

Sadık Erdaş, "Hatıralar Işığında Kafkas Cephesi’nde Yaşanan Temel Sorunlar ve Gözlemler”, Haz. Merve Uğur, 100. Yılı Münasebetiyle I. Dünya Savaşı’nda Kafkas (Doğu) Cephesi Uluslararası Sempozyumu, Atatürk Araştırma Merkezi Yayınları, Ankara 2015, s. 680.

HRT.h... 1305, H. 29.05.1335/23 Mart 1917.

DH. UMVM 41-5, H. 17.07.1338/21 Mart 1920. 
metre yolun inşa edilmesi planlanmıştır. Ancak kaynak sağlanamadığı için 1908 Nafia Programının uygulanması mümkün olmamış, her vilayetin tarik varidatı miktarınca yol yapımının sağlanması kararı alınmıştı. Bitlis gibi yol vergilerinin düşük olduğu vilayetlerde yolların inşası konusunda çabalar mali kaynakların yeterli olmaması nedeniyle genellikle sonuçsuz kalmıştır. Nafia Programının uygulanamaması nedeniyle 1910 yılında bazı vilayet yolları da dâhil edilerek 10.000 kilometre yolun inşa edilmesi kararlaştırılmış ve bu yolların inşa imtiyazı Fransız İnşaat Şirketi’ne verilmişti. Fransız İnşaat Şirketi Bitlis Vilayeti dâhilinde devlet yolları kapsamında olan hatlar üzerinde hiçbir çalışma yapamadan I. Dünya Savaşı başlamış ve bu savaşta Fransa ile Osmanlı Devleti farklı bloklarda yer aldığ1 için İnşaat Şirketi'nin sözleşmesi feshedilmiştir. I. Dünya Savaşı esnasında seferberliğin ilan edilmesi, ahalinin yollarda çalıştırılması, amele taburları ile askeri açıdan önem arz eden yolların inşa edilmesine çalışılmıştı. Bu çabalar Bitlis Vilayeti'nde yolların muntazaman yapılması, tamir ve inşalarının temin edilmesi gibi bir sonuç doğurmamış, bilakis yollar üzerinde nakliyat arttığı için mevcut yolların daha da bozulmasına sebep olmuştur.

\section{Kaynakça}

Arşiv Kaynakları

Başbakanlık Osmanlı Arşivi (BOA)

BEO (Babıâli Evrak Odası)

$3588-269034$

4168-312582

4206-315437

4306-322890

4308-322053

4308-323089

DH. İD. (Dâhiliye Nezareti İdare Evrakı)

3-18

DH. MKT. (Dâhiliye Nezareti Mektubi Kalemi)

271-94

286-103

2881-13

DH. ŞFR. (Dâhiliye Nezareti Şifre Evrakı)

43-214

47-132

DH. UMVM. (Dâhiliye Nezareti Umur-1 Mahalliye ve Vilayat Müdürlügü Evrakı)

41-5

74-31

HRT.h...(Haritalar) 


\section{5}

İ. MLU. (İrade Meclis-i Umumi)

8-5

MV. (Meclis-i Vükela Mazbataları)

176-64

$178-30$

\section{Diğer Kaynaklar}

Atam, Şenay. Osmanlı Devleti'nde Nafia Nezareti, Yayımlanmamış Doktora Tezi, Niğde Üniversitesi Sosyal Bilimler Enstitüsü, Niğde 2015.

Berksan, Nazım. Yol Davamız, Akın Matbaası, Ankara 1951.

Cırık, Bülent. İkinci Meşrutiyet Döneminde Bitlis Sancağı (1908-1914), Yayımlanmamış Doktora Tezi, Sakarya Üniversitesi Sosyal Bilimler Enstitüsü, Sakarya 2015.

Çetin, Emrah. Tanzimat'tan II. Meşrutiyet'e Anadolu'da Karayolu Ulaşımı, Türk Tarih Kurumu Yayınları, Ankara 2017.

Erdaş, Sadık. "Hatıralar Işı̆̆ında Kafkas Cephesi'nde Yaşanan Temel Sorunlar ve Gözlemler”, Haz. Merve Uğur, 100. Yılı Münasebetiyle I. Dünya Savaşı’nda Kafkas (Doğu) Cephesi Uluslararası Seтроzуuтu, Atatürk Araştırma Merkezi Yayınları, Ankara 2015, ss.665-696.

İsmail Hakkı Bey, Raporlarım, Osmanlı Matbaası, Adana 1328 (1912).

K1sa, Ahmet. Osmanlı Devleti’nde Bayındırlık Faaliyetleri (1908-1918); Kapitülasyonlar, Imtiyazlar, Anonim Şirketler, Yayımlanmamış Doktora Tezi, Akdeniz Üniversitesi Sosyal Bilimler Enstitüsü, Antalya 2019.

Meclis-i Mebusan Zabıt Ceridesi, 1. Dönem, 1. İçtima, 5. Cilt, İ. 105, 20 Haziran 1325/3 Temmuz 1909.

Meclis-i Mebusan Zabıt Ceridesi, 1. Dönem, 1. İçtima, 6. Cilt, İ. 137, 5 Ağustos 1325/18 Ağustos 1909.

Meclis-i Mebusan Zabıt Ceridesi, 1. Dönem, 1. İçtima, 6. Cilt, İ. 132, 31 Temmuz 1325/13 Ağustos 1909.

Şen, Korkmaz.“'Osmanlı Arşiv Belgelerinde Muş Köprüleri”, Türkiyat Mecmuası, 2019.

Tekdal, Danyal. II. Abdülhamit Dönemi’nde Bitlis Vilayeti (İdari ve Sosyal Yapı). Yayımlanmamış Doktora Tezi, Pamukkale Üniversitesi, Sosyal Bilimler Enstitüsü, Denizli 2018.

Umur-ı Nafiaya Dair Layiha. Ticaret ve Nafia Nezareti, İstanbul 1908.

Vilayet Yolları Haritası. Dâhiliye Nezareti Umur-1 Mahalliye ve Vilayet Müdüriyeti, Hilal Matbaas1, İstanbul 1913.

Yıldırım, Yıldıray. "Bir Devlet Adamı Olarak İsmail Hakkı Bey ve Adana Valiliği Dönemi'ndeki Faaliyetleri (1914-1916)", Ed. Erdem Çanak, M. Fatih Sansar, II. Uluslararası Multidisipliner Çalışmaları Kongresi, Akademisyen Kitabevi, Ankara, ss. 91-108. 